\title{
Sofus Larsen
}

\author{
Af A. G. Drachmann
}

Sophus Christian Larsen blev født i 1855 i København paa Almindeligt Hospital, som Søn af Overkirurg, dr.med., siden Etatsraad Søren Eskild Larsen og Hustru Sophia Albertina, født Matzen. Han er saaledes opvokset $i$ et velstaaende, ${ }^{1}$ akademisk Hjem i København, hans Fader, der var født i 1802, døde i $1890{ }^{2}$

Han var døbt Sophus Christian Larsen, med ph og ch, men ændrede senere Stavemaaden til fog $\mathrm{k}$, antagelig under Paavirkning fra Højskolekredse.

Han blev Student i 1872, cand.philol. i 1880; i 1883 blev han Assistent ved Universitetsbiblioteket, og i 1899 Underbibliotekar, Bibliotekar i 1907 og Overbibliotekar i 1909. I 1925 fratraadte han Stillingen som 70-aarig, og han døde i 1938, 83 Aar gammel. ${ }^{3}$

Stillingen paa Biblioteket med kun 5 Timers dagligt Arbejde gav ham Muligheder for at dyrke videnskabelige Studier, og det maa siges, at han forsømte dem ikke. Han var hele sit Liv en meget flittig Mand.

I 1885 fik han Universitetets Guldmedaille for en Afhandling om De bello Alexandrino, og i 1889 tog han Doktorgraden paa en Disputats om Plutarchs Moralia; disse to Værker laa inden for hans Fag, som var klassisk Filologi, og han ydede endnu et Bidrag hertil, idet han skrev et Afsnit om det romerske Samfund i Republikkens Tid til Verdenskulturens 2. Bind, 1905-6 (andre Bidragydere til dette Bind var Sophus Müller, Kr. Erslev, J. L. Heiberg og A. B. Drachmann,

Dr. phil. A. G. Drachmann (1891-1980) var bibliotekar ved Universitetsbiblioteket, København, 1915-56. 
saa han var i pænt Selskab). Men han havde allerede den Gang forladt den klassiske Filologi og var begyndt paa det, som skulle blive hans Hovedinteresse: Studiet af de danske Folkeviser og i det hele taget den danske Middelalders Kultur [og Historie]. Han begyndte i Aarbøger for nordisk Oldkyndighed med Folkevisen om Liden Kirsten og Prins Buris i 1887, og Kritiske Studier over vore Folkeviser i Dania i 1902; saa kom Monografier om Niels Ebbesens Vise i 1908, Fire danske Viser fra Middelalderen 1923, Ebbe Skammelsen 1924 og Visen om Marsk Stig og hans Hustru 1937.

Af andre Bøger kan nævnes: Antik og nordisk Drømmetro 1917, Saxo Grammaticus 1925, om Jomsborg 1927-28 og 1931 (begge i Aarbøger for nordisk Oldkyndighed) og Kilderne til Olaf Tryggvesøns Saga 1932. ${ }^{4}$

En kortvarig international Berømmelse opnaaede han, da han ved den 21. internationale Kongres af Amerikanister i Gøteborg forelagde en Undersøgelse, der beviste, at portugisiske Sømænd havde været i Land i Amerika før Columbus; den er trykt som Bog i 1924.

Hans Folkevisestudier er uhyre grundige; de tre Bøger om enkelte Viser: Niels Ebbesen, Ebbe Skammelsen og Marsk Stig, er hver paa flere hundrede Sider, med Indledning om de historiske Begivenheder, den kulturelle Baggrund og Visens Overlevering, med Optryk af samtlige Opskrifter efter Svend Grundtvigs store Udgave; derpaa den rekonstituerede Vise med udførlig Kommentar, Vers for Vers, Linie for Linie. Man kan dog ikke sige, at han høstede stor Anerkendelse fra andre Fagmænd herhjemme; tværtimod, han kom hurtigt i Haar sammen med [Axel] Olrik og Ernst von der Recke og alle andre, som beskæftigede sig med Folkeviser den Gang.

Jeg har hørt sige, baade den Gang og nu, at det skulde skyldes, at Sofus Larsen vilde anvende den klassiske Filologis Metode paa Folkeviserne, hvor den ikke er egnet. Det er nu at gøre Uret baade mod Sofus Larsen og mod den klassiske Filologis Metode. I en af sine Indledninger ${ }^{5}$ gør han rede for sin Metode; han hævder, at den klassiske Filologis Metode er fortrinlig, hvor det gælder en skriftlig Overlevering, som maa antages at gaa tilbage til den antikke Forfatters egenhændige Manuskript; men da Folkevisernes Optegnelser beror paa en mundtlig Tradition, som har været virksom i mange 
hundrede Aar, og som ikke kan antages at gaa tilbage til et Manuskript, maa der tages skyldig Hensyn hertil. Ved Hjælp af nogle tænkte Eksempler paa, hvordan Overleveringen kan have fundet Sted, naar han til det Resultat, at man ikke kan forvente, at nogen enkelt Optegnelse skulde indeholde den helt fuldstændige og korrekte Tekst, medens man alligevel ikke tør udelukke, at selv en ellers meget ringe Optegnelse kan være ene om at bringe enkelte, originale Linier. Følgen maa blive, at Udgiveren maa vælge og vrage mellem alle de overleverede Linier, til han finder en brugelig Form for hvert Vers.

Dette er i Virkeligheden ikke væsensforskelligt fra hvad de andre Udgivere gør og er nødt til at gøre, men Sofus Larsen er nu meget haardhændet og betænker sig ikke paa helt at kassere Linier og erstatte dem med sine egne, hvis han intet Sted kan finde en Linie, der huer ham. Jeg skal give et Eksempel paa, hvor vidt Sofus Larsens Metode kunde føre, naar den var parret med en mærkelig Ufølsomhed over for det danske Sprog.

Verset, der skildrer hvorledes Niels Ebbesen trænger ind i Grev Gerts Sovekammer, lyder gerne saadan:

De stødte paa Dør med Skjold og Spyd, de Nagler ginge alle i Stykke.

Est du herinde, Greve Gert, vi vil dig en Skaal tildrikke.

[Sofus Larsens Tolkning er denne:] Første Linie skal være: De stødte Døren op med Spjud - af metriske Grunde. Anden Linie er ogsaa forkert, det er utænkeligt, at alle Naglerne skulde gaa itu. Der skal læses: De Nagler alle stukke, hvilket her ikke skal betyde, at de gaar itu, men at de springer ud afideres Plads og farer ind i Stuen, hvor de rammer Grev Gert. Dette belægges ved Linier fra andre Folkeviser.

Tredie Linie er nemlig ogsaa forkert. Spørgsmaalet: Est du herinde? er urimeligt, da Greven allerede har svaret Budet gennem Døren. Vi læser derfor: imod Grev Gerit, inde var, og skal saa bringe sidste Linie til at stemme. Her er Sofus Larsens egne Ord: ${ }^{6}$

»For at give dette et drastisk og prægnant Udtryk har Forfatteren 
i sidste Linie benyttet sig af en Lignelse, et Billede, som endnu lever i Sprogets lavere Lag: at drikke én en Skalle. Formen Skalle, som er identisk med den middelalderlige Betegnelse for Skaal, Drikkekar, en Skale, viser, at dette tekniske Slagsbroderudtryk gaar langt tilbage i Tiden. Dets egnl. Betydning er at klinke med en, støde sin Skaal mod en andens, og naar man ved, hvorledes en Skalle drikkes, kan det ikke nægtes, at Billedet er ret betegnende. Anvendt paa det foreliggende Sted vil det altsaa sige, at Dørens Nagler ved Stødet farer hen imod Greven og drikker ham Skaller.

Ud fra disse Synspunkter foreslaar jeg at rette den forvanskede Strofe saaledes:

The støttæ døren up mæth spiuth, thæt naglær allæ stukkæ amoth gref Gerith, innæn war, oc hanum skalær drukkæ.

Drukka er den gamle Fortids Flertalsform af Verbet drikke."

Dette er ganske vist et meget yderliggaaende Eksempel, men det er ikke enestaaende. Det synes klart, at en Fortolkningskunst, som kan føre til et saadant Resultat, ikke har mange Muligheder for at vinde almindelig Tilslutning. Men Sofus Larsen var slet ikke nogen dum Mand, saa man staar underlig uforstaaende over for dette Fænomen. Man faar et Indtryk af en Art Kortslutning, hvorved den kritiske Evne bliver sat fra Bestillingen. Og det giver en ubehagelig Følelse af Utryghed over for alle Forfatterens øvrige Resultater.

Foruden de her omtalte Arbejder har Sofus Larsen skrevet mange Bidrag om Biblioteksforhold, men de vil blive omtalt senere.

Dette er saa meget, som man kan faa at vide ved at gaa til de tilgængelige Kilder: Dumreichers Biografi i Dansk Biografisk Leksikon, Kraks Blaa Bog, Dansk Bogfortegnelse o.s.v. Nu vil jeg gaa over til min egentlige Opgave: at skildre mit personlige Indtryk af Sofus Larsen som Menneske og som Bibliotekar.

De trykte Kilder giver allerede en Del af hans Karakteristik. Vi ser en velbegavet og flittig Mand, som er i Besiddelse af en stor Viden; en Mand, som interesserer sig for mange Ting og gerne arbejder 
med dem; men det maa desværre tillige erkendes, at der aldrig kom noget rigtigt ud af det; hans Arbejder har ikke sat sig Spor til vore Dage. Det Brudstykke, jeg har citeret af hans Bøger om Folkeviser, taler sit tydelige Sprog; han har manglet Sans for det danske Sprog og tillige almindelig, sund Fornuft til at kontrollere de Slutninger, hans Undersøgelser førte ham til.

Jeg traf ham første Gang i 1913, da jeg kom ind paa Biblioteket som Volontør; i 1915 blev jeg ansat som ekstraordinær Medarbejder, i 1917 blev jeg Underbibliotekar, og indtil 1925, da Sofus Larsen faldt for Aldersgrænsen, har jeg daglig haft Lejlighed til at være sammen med ham. ${ }^{7}$

Han var ret lille af Vækst, ikke nogen Splejs, heller ikke nogen Tyksak, men hvad man kunde kalde undersætsig. Hans Ansigt var rundt, og han bar et hvidt, spidst, kortklippet Fuldskæg. Han var skaldet og gik altid paa Biblioteket med en lille, sort Kalot; det store Biblioteksrum var ikke særlig godt opvarmet, og der var Grund til at beskytte sig mod Træk i Hovedet. Kalotten var en uadskillelig Del af hans Ydre; dog har jeg set ham en enkelt Gang, da der var noget at raabe Hurra for, tage Kalotten af og svinge med den.

Jeg kan ikke huske, at jeg har set det mere end een Gang, men denne lille Gestus føltes som uhyre karakteristisk for ham.

Et Hovedtræk ved hans Karakter var hans Elskværdighed. Der er en lille Historie, jeg har hørt, jeg husker ikke af hvem. Sofus Larsen boede om Sommeren i en Villa med Have ned til en Sø; langs Søen gik en Sti forbi Haven. Nogle Drenge paa Fodtur var kommet ind paa Stien og saa pludselig en lille, gammel Mand styrende i fuld Fart ned imod sig. De blev lidt benovede, for de var ikke sikre paa, om de ikke var kommet ind paa en privat Grund. Alt hvad Sofus Larsen vilde dem, var at anvise dem nogle Stikkelsbærbuske med modne Bær, som de kunde spise af.

Saaledes var Sofus Larsen. Han kunde gaa meget vidt, til Tider endda maaske for vidt, i sit Ønske om at være god mod Folk, at hjælpe; jeg skal komme tilbage til det senere. Men der var intet holdningsløst $i$ hans Elskværdighed. Han havde en klar Følelse af sit eget Værd, og han fandt sig ikke i, at nogen tog sig Friheder med ham. 
Sofus Larsen, 35-40 år gammel, uden den for ham så karakteristiske kalot. Fotograferet hos L. Winther, der havde atelier $i$ Vimmelskaftet $47 \mathrm{ca}$. 1890-ca. 1895. Det kgl. Bibliotek, Billedsamlingen.

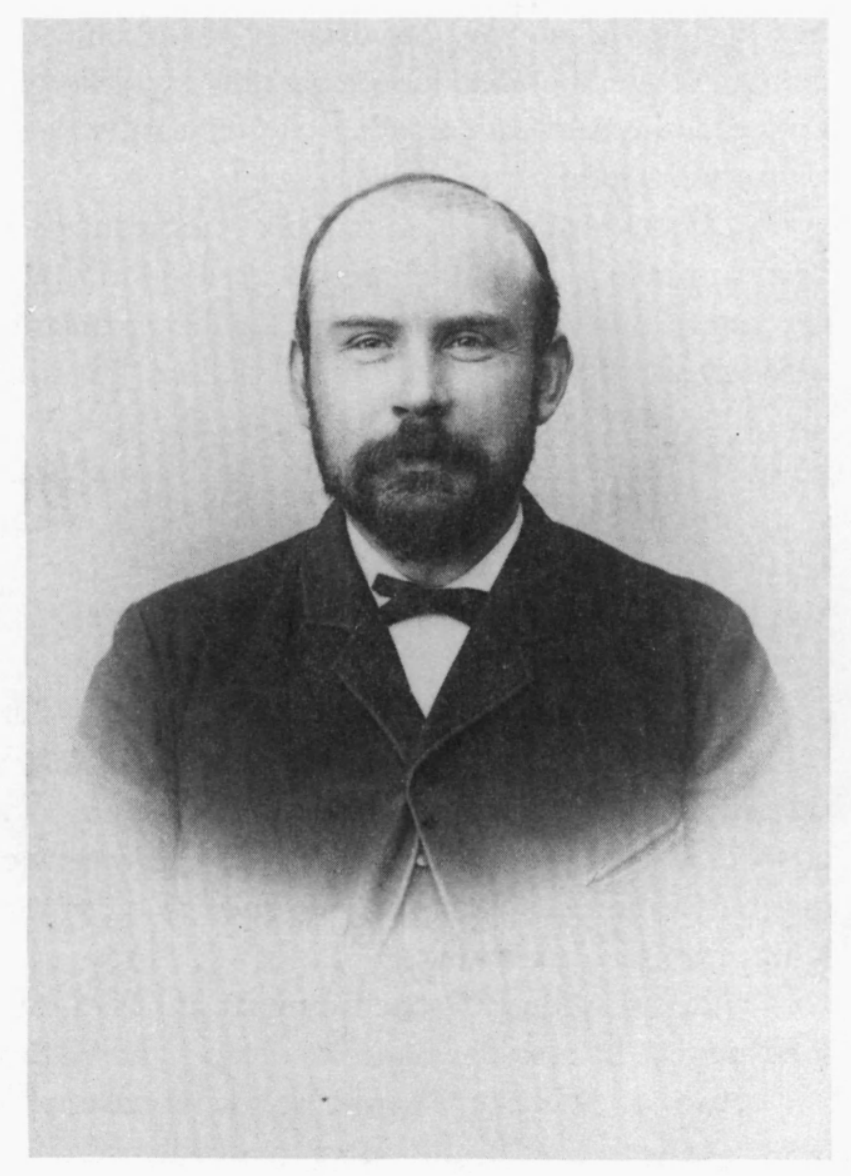

Hans Forhold til Personalet var godmodigt patriarkalsk. Han havde fra Birket-Smith overtaget den Skik hver Formiddag at gaa rundt og give Haanden til os alle, altid venlig og hyggelig. Men der var ingen Tvivl, hverken hos ham eller andre om, hvem der var Overbibliotekaren, hvem der havde det sidste Ord om, hvor Skabet skulde staa, hvis der opstod Tvivl om dets Plads.

Et andet Træk hos ham var hans Retsindighed. Aldrig har jeg oplevet eller hørt at han havde gjort noget, som ikke var aabent, ærligt, retsindigt. Lusk og Svig og enhver Form for Underfundig- 
hed og Uærlighed var ham usigelig fremmed. Han kunde tage Fejl, det kan vi alle; men han kunde ikke med Vilje begaa noget, som man kunde rynke paa Næsen ad. Hans Ord stod til troende, man vidste, hvor man havde ham. ${ }^{9}$

Hvad man nu kalder Klimaet paa Arbejdspladsen var under Sofus Larsen fortrinligt. Han havde fra Birket-Smith overtaget et veloplært og disciplineret Personale, og her fortsatte han paa bedste Maade hans Værk. Der var god Disciplin, man mødte til Tiden og gik ikke før Tiden og man passede sit Arbejde. Samarbejdet var godt, Tonen kammeratlig, elskværdig, hjælpsom; man var som én stor Familie. Selv i de bedste Familier kan man komme op at skændes, og det kunde man ogsaa her; men det var kun Storme i et Glas Vand, og de efterlod aldrig varig Misstemning. Dertil var Grundindstillingen for solid.

Sofus Larsen var en pligtopfyldende Mand. Han havde et godt Helbred, og han forsømte næsten aldrig en Dag på Biblioteket. I sine sidste Aar i Embedet var han plaget af en Lidelse, som hedder Helvedesild, og som ikke bærer sit Navn forgæves. Men han kom ind paa Biblioteket, selv om det kun førte til, at han sad i Sofaen i sit Kontor og havde det ondt.

Han var, som det allerede fremgaar af hans Levnedsløb, en Mand med mange Interesser. Han blev let begejstret for det ene eller det andet, og saa vilde han gerne, at Omgivelserne skulde tage Del i hans Glæde. "Er det dog ikke et dejligt Bind?" "Se paa det her Bogtrykkermærke; er det dog ikke morsomt? - til hvem som helst af hans Kolleger, ældre som yngre. Og vi var glade med ham, for man kunde ikke andet.

Men det skal ikke skjules, at der sammen med denne umiddelbare Glæde hos ham boede et Træk af Barnlighed, som kunde have uventede og uønskede Følger. Ogsaa det skal jeg komme tilbage til.

Med alle disse fortræffelige Egenskaber maatte man forvente, at Sofus Larsen kunde være blevet en dygtig og effektiv Chef for Universitetsbiblioteket. Naar han alligevel ikke helt blev det, kan Aarsagen angives med faa Ord: han var ikke Bibliotekar. Han var aldrig andet end en velmenende Dilettant. Som Biblioteksmand tilhørte han, hvad.jeg engang har betegnet som "en med Rette forladt 
Fortid « - den Tid, hvor man regnede med, at Biblioteksarbejde var noget, enhver oplyst og velbegavet Mand uden videre kunde paatage sig. Men den Type Bibliotekar var Tiden løbet fra.

Hans Forgænger, Birket-Smith, havde i 1880 overtaget Biblioteket $i$ en meget miserabel Forfatning og var gaaet i Gang med at forbedre det. Sit Forbillede for de nye, systematiske Kataloger havde han søgt $\mathrm{i}$ Tyskland, men antagelig paa grund af [Krigen i] 1864 ikke i Preussische Staatsbibliothek i Berlin, men i Bayerische Staatsbibliothek i München. Han havde faaet Personalet udvidet, saa at det nu bestod af 2 Bibliotekarer og 9 Underbibliotekarer, mod 4 ved hans Tiltrædelse, og han havde uddannet og skolet dette Personale, saa at de kunde deres Ting og tillige samarbejdede paa bedste Maade. Alt dette omtaler Sofus Larsen i sine smukke Mindeord om Birket-Smith i bogen Ex Bibliotheca Universitatis Hauniensis, som udkom i $1920{ }^{10}$ han siger om ham: "Han har skabt det Grundlag, som vi stadig maa bygge videre paa, og som vi kan bygge videre paa. "Det betød i Praksis, at Sofus Larsen ansaa dette Arbejde for at være sat i Gang og være i god Gænge, og saa interesserede det ham ikke.

Han var, som sagt, en pligtopfyldende Mand. Han besørgede Bogindkøbet og han passede Regnskabet, gjorde det Rutinearbejde, der paahvilede ham. Han alene bestemte Bogkøbet; dog fik han i 1918 to Konsulenter til at hjælpe sig med den medicinske Litteratur. I øvrigt helligede han sig de Ting, som havde hans specielle Interesse. Heriblandt var det Konserveringen af Bibliotekets Haandskriftsamling, derunder de Arnemagnæanske Haandskrifter. Det var godt og rigtigt, at det blev gjort. Nu har vi en internationalt anerkendt Ekspert til at tage sig af de Arnemagnæanske Haandskrifter, og hvad der skete i Sofus Larsens Tid er maaske nu ikke tilfredsstillende; men som det blev gjort, var det det bedste, der kunde præsteres den Gang.

Men man kan nok kritisere den Disposition, Sofus Larsen traf i den Anledning. Biblioteket var normeret med 1 Overbibliotekar, 2 Bibliotekarer, 9 Underbibliotekarer, 1 Kustode og 2 Betjente. Bibliotekets Bogbinder, Ehlert, havde en Svend, Friese, som var meget dygtig og meget omhyggelig netop til den Art Arbejde. Ved 
første Lejlighed fik Sofus Larsen ham ansat som Betjent ved Biblioteket, og da mindst hans halve Arbejdstid gik med at reparere Haandskrifter, gik Biblioteket glip af en halv Betjent paa et Tidspunkt, da der var stor Mangel paa underordnet Arbejdskraft. Ret beset betød det, at en Underbibliotekar maatte udføre Betjentarbejde en Del af sin Tid. Men saadan en Betragtning laa Sofus Larsen fjernt.

Ogsaa paa andre Punkter kan hans Personalepolitik kritiseres. Reglen var, at man til Underbibliotekarer valgte Folk med Embedseksamen, idet den korte Arbejdstid, 5 Timer daglig, forudsatte, at de stadig arbejdede videre i deres Fag. Dette havde den Ulempe, at nogle af dem forlod Biblioteket for at blive Professorer, som Dines Andersen og Aage Friis; men det bevirkede dog en høj Standard for Bibliotekets Personale, selv om det ikke med Urette kunde siges, at en Del af deres Arbejde var som at skrælle Kartofler med Rageknive. ${ }^{11}$

Det er svært for Nutidens Biblioteksfolk at forestille sig en Ordning, hvor næsten alt Arbejdet, fra Nykatalogisering af en Afdeling til Fremtagning og Indsætning af Bøger, Ordning af Sedler, Udskrivning af Hjemkaldelser, blev foretaget af Folk med Embedseksamen, eller Doktorgrad. Nu er Arbejdet delt op i Grader, og der er Klasser af Personalet, til hver Grad af Arbejdet, fra Førstebibliotekarer ned til Folk, der fra Gaden, saa at sige, tages ind paa »Foranstaltningen «. Selvfølgelig var man klar over, at ikke alt Biblioteksarbejde krævede en fuld akademisk Uddannelse; det var ikke langt fra at man mente, at hvis en Mand ikke duede til andet, kunde han bare komme ind paa et Bibliotek. Jeg er selv blevet trukket hen i en Krog af en eller anden pæn Mand, som har forklaret, at han havde en Nevø, eller hvad det nu var, der ikke rigtig kunde begaa sig; om han ikke kunde komme ind paa Biblioteket. I stedet for kort og godt at spørge: "Tror du, det er fordi.jeg er Idiot, jeg sidder der? " plejede jeg at forklare, at saadan var det maaske en Gang for nogen Tid siden, men nu var Forholdet anderledes; der stilledes større Krav. Og .jeg tilføjede ikke, hvad der dog var indlysende, at hvis Biblioteket for de samme Penge kunde faa en dygtig Mand, vilde det være urimeligt, om det med Vilje valgte en, som der var noget $\mathrm{i}$ 
Vejen med. I en Tid, hvor det var enten Underbibliotekar eller slet ikke, var det dog en rimelig Betragtning.

Men selve Tanken var ikke uddød, og udtrykket "Akademisk Amerika " som vist [Johan Stockfleth] Eyser var Ophavsmand til, var ikke uden Berettigelse. Eyser var blevet ansat af Birket-Smith, og han havde ingen Eksamen. Men han havde læst Sanskrit og Persisk og havde gaaet Vilhelm Thomsen til Haande, ${ }^{12}$ med disse Specialkundskaber var det ikke urimeligt at ansætte ham. Nogen Eksamen tog han ikke. "Jeg har tænkt mig at gaa op sammen med H. O. Lange og Vilhelm Grundtvig, " sagde han, hvis man hentydede til det.

Den første, Sofus Larsen ansatte, var Frederik Birket-Smith, Forgængerens Søn. Han havde studeret Medicin, men var gaaet over til Kunst og Musik; han havde ingen Eksamen. Hans Fader havde ikke villet ansætte ham, men Sofus Larsen tog ham. Faktisk mener jeg, at han gjorde god Fyldest. Ikke saadan som to andre, som endnu levede i Mindet, da jeg kom derind. Ingen af dem havde Eksamen. Aage Schmidth var Søn af brave Forældre og havde Fortalere blandt Professorerne; han blev foretrukket for en Dr.phil., og blev afskediget, da han spadserede paa Strøget en Dag, han var sygemeldt. Moritz havde heller ingen Eksamen, men det var ikke, fordi han ikke prøvede; han dumpede fem Gange til Magisterkonferens i sammenlignende Litteraturhistorie, og hans Vankundighed skal have været æventyrlig. Han gik til Filmen, hvor han fik et godt Job.

$\mathrm{O}$ [tto] S[everin] Jensen, ${ }^{13}$ den ældste af Bibliotekarerne, var en dygtig Embedsmand, men saa med kritiske Øjne paa sine Kolleger; det var ham, der udtalte, at der kun fandtes to Slags: de, der ingen Ting bestilte, og de, der gjorde al Ting forkert. Spurgte man ham om, hvilken Klasse han selv hørte til, svarede han, at han hørte til den første Klasse. Han var en heldig Kartoffel, et lykkeligt Svin, siden han var kommet ind paa en Anstalt - en Lemmehave, nemlig noget imellem en Børnehave og en Forsørgelsesanstalt - hvor der ikke krævedes, at man skulde præstere et virkeligt Arbejde. Det maa bemærkes, at han med nogen Hjælp fra et ældre Bud alene Mand modtog og kontrollerede hele den danske Pligtaflevering fra Bogtrykkerne, og gjorde det fortrinligt. 
De nye Ansættelser skal han have kommentret saaledes, idet han stod i Bogsalen og henvendte sig til en af de Støbejernssøjler, som bærer Taget. "I gamle Dage ansatte man som Bibliotekarer Videnskabsmænd. Nu ansætter man Journalister. Næste Gang bliver det nok Alfonser."

Men fra nu af ansatte Sofus Larsen kun Folk med Embedseksamen i Bibliotekarstillinger. Men han havde endnu et Uheld, som dog ikke helt kan lægges ham til Last. Paa Konsistoriums Kontor havde de et Bud, som havde vist sig noget upaalidelig. De vilde derfor gerne have ham flyttet til Universitetsbiblioteket, fordi de haabede, at han med den faste Arbejdstid inden for Murene vilde kunne gøre Fyldest. En mindre godlidende Mand vilde have sagt nej, men man maa ikke glemme, at Biblioteket var en Del af Universitetet, og Konsistorium altsaa en overordnet Instans. Manden blev derfor ansat, og det var ikke nogen Sukces. Han var en gennemupaalidelig Person, uærlig i Pengesager, og meget lidt Værd i sit Arbejde. Aage Dons har i "Koncerten" [1935] givet et meget lidt flatterende, men vist i Hovedsagen korrekt Portræt af ham under Navnet "Hask«. Gang paa Gang maatte Sofus Larsen holde Møder med hans Kreditorer og Folk, som han havde ført bag Lyset, men alt hvad der lykkedes ham var at faa Afgørelsen udsat, til det blev hans Efterfølger, som kom til at afskedige Manden. Ansættelsen burde aldrig have fundet Sted, og Afskedigelsen kunde have været foretaget meget, meget tidligere.

Det var Sofus Larsens Interesse for Konservering af Haandskrifterne, som førte over til min Omtale af hans Ansættelser. Men han interesserede sig ogsaa for andet; han glædede sig over de smukke Bind, hvor de fandtes, fik dem katalogiserede og restaurerede, hvor det behøvedes; Bøgerne fik et Beskyttelsesomslag af graat Karduspapir. Som altid gjorde han noget ud af det. Han satte sig ind i de dekorerede Binds Historie og skrev sammen med Anker Kyster en Bog om dem. ${ }^{14}$ Men det gav ogsaa Bagslag. Han købte hos Levin \& Munksgaard nogle franske Bøger i "smukke, samtidige Bind ", uden Hensyn til, at deres Indhold ikke gjorde dem værdige til en Plads i Biblioteket. Mit Indtryk er, at det var nogle Bøger, Boghandelen 
havde brændt sig paa, og at de benyttede sig af Overbibliotekarens Interesse til at faa dem solgt.

I 1920 udgav han et Værk, Disputatio contra mulieres, fra 1511, hvori det bevises, at Kvinder ikke er Mennesker. Det er en ganske pudsig lille Ting, som kom hos Levin \& Munksgaard i et meget nitidt Udstyr. Det morede Sofus Larsen meget at faa Mulighed for at udgive det; men det kan ikke nægtes, at der hist og her blev mumlet lidt om, at det muligvis var mindre korrekt, at Chefen for en Statsinstitution modtog en saadan Cadeau fra et Firma, som var meget interesseret $i$ at faa Leverance til Institutionen. Jeg tvivler paa, at nogen sagde det til ham selv, og jeg er ganske overbevist om, at han vilde have været helt ude af Stand til at forstaa det, hvis det var blevet sagt. Det var en god Ting, at Værket blev udgivet, og det var smukt, at Levin \& Munksgaard vilde bekoste Udgivelsen. Det var det hele. Hans Retsindighed var alt for massiv til at han kunde tiltro andre Hensigter, som aldrig vilde være faldet ham selv ind.

Det generede ham, naar smukke Tavleværker, der blev sendt til Reproduktionsanstalter, kom tilbage med sorte Fingeraftryk i Marginen. Han besluttede derfor, at Biblioteket selv skulde levere Fotografier til Reproduktion. Der blev indrettet et Mørkekammer paa fjerde Sal i Nye Bygning og købt et Udstyr til at tage Fotografier og Fotostatkopier, og en af Underbibliotekarerne, det var mig, blev sat til at passe det. Jeg kom paa Kursus paa fotografisk fotokemisk Laboratorium, hos Professor Winther, ${ }^{15}$ og lærte at fotografere, baade med almindeligt Lys og med infrarødt og ultraviolet Lys; jeg lærte ogsaa at lave Bromolietryk, saa at jeg kunde levere Kopier af manglende Titelblade trykt paa gammelt Papir, som jeg fik af Friese, der fik gamle Blade tilovers, naar han konserverede Haandskrifter og gamle Bøger. Det morede mig, men det var egentlig ikke det, jeg havde Uddannelse til og fik Løn for. Det var atter et Udslag af Mangel paa Forstaaelse af Arbejdets Betydning, og egentlig Misbrug af Stillingen som Chef.

Men det hang igen sammen med hans Personalepolitik. Dumreicher fremhæver i sin Biografi af ham, at han sørgede for at skaffe Personalet bedre Løn, et Punkt, som Birket-Smith havde forsømt, 
og at han skaffede Biblioteket mere Personale, hvad der var tiltrængt. ${ }^{16}$ I 1909 , da han tiltraadte som Overbibliotekar, bestod Personalet af 2 Bibliotekarer og 7 Underbibliotekarer; i 1925 var der 6 Bibliotekarer og 10 Underbibliotekarer. ${ }^{17}$

En meget vigtig Ting er Forholdet til Publikum. Her gik Sofus Larsen trofast i Birket-Smiths Spor. Der var en lille Historie, som jeg hørte, da jeg var blevet ansat. En Underbibliotekar havde ekspederet en Laaner høfligt, men noget køligt; da Laaneren var gaaet, gik Birket-Smith hen og lagde Haanden paa Underbibliotekarens Skulder og sagde: "Husk paa, kære Friis, at en Bibliotekar skal ikke blot være høflig, han skal ogsaa være elskværdig. " Jeg husker en lille Oplevelse, jeg selv havde. Hvad der var gaaet forud, veed jeg ikke; det maa have været, at Jensen havde betjent en Laaner paa Læsesalen daarligt, og [Balder] Erichsen, som ellers aldrig gjorde Vrøvl, tog ham i Skole. Det jeg hørte ham sige lød som et Litani, der maa stamme fra Birket-Smiths Tid: "Gaa hen til Laaneren, indlad Dem med ham, se at finde ud af, hvad det er, han søger."

Læsesalen var aaben og frit tilgængelig for enhver. Der var en Grænse, men den var langt ude. En Gang havde nogle Laanere klaget over, at en anden Laaner paa Læsesalen var for snavset. [Alfred] Krarup forelagde Sagen for Sofus Larsen, som dekreterede, at hvis Manden var saa snavset, at han forulempede de omkringsiddende ved ilde Lugt, burde han bortvises, og saa gik han selv op paa Læsesalen for at undersøge Sagen. Jeg har ingen klar Erindring om, hvad der skete, men jeg tror, at Manden fik Lov til at blive siddende. Hvis han var blevet bortvist, havde det været noget saa enestaaende, at jeg sikkert havde husket det.

Vi ser her Sofus Larsen saa at sige fra alle Sider: hans absolutte Regeringsform, hans Menneskevenlighed og liberale Indstilling, hans Pligttroskab, men tillige hans Fasthed. Hvis han havde skønnet, at Laaneren var uantagelig, vilde han have bortvist ham, omend meget imod sin Tilbøjelighed.

Han var ogsaa interesseret i tekniske Forbedringer, hvor de tiltrængtes. De nye alfabetiske Kataloger var anbragt i Trækasser, der lignede Bøger og stod paa Reoler. Der skulde et vist Haandelag til at bruge dem, og det lærte Bibliotekarerne hurtigt; men de var ikke 
beregnet paa Publikum, og hvad skulde det ogsaa med dem? De behøvede jo blot at sige, hvad de vilde have for en Bog, saa fik de den.

De systematiske Kataloger, som Publikum kunde faa Brug for, var skrevet paa store Sedler, som var klemt fast mellem to Papplader; der var to Messinglister og to Skruer med Fløjmøttrikker, som klemte dem sammen. Den ene Papplade havde et Hængsel, saa den kunde løftes, og man kunde blade i Sedlerne; men fast sad de. Disse Skruebind maatte ligge paa Hylderne oven paa hinanden, og saa ragede Skruerne op, og de var svære at faa fat i, og det blev jo ikke bedre af, at de ofte laa højt oppe, saa at man maatte op paa en Stige for at faa fat i dem.

Sofus Larsen søgte Hjælp hos en Mekaniker og lavede nogle Skruebind, som kunde staa som Bøger paa Reolen; det sparede Plads og var meget mere haandterligt. Desværre var Konstruktionen ikke særlig effektiv. Bindet kunde kun lukkes med en særlig Presse, og da dette sprang let op igen, maatte man skære Hovedet af Skruerne. ${ }^{18}$ Saa, efter flere Aars Forløb, naaede man til en bedre Konstruktion; man brugte forsænkede Skruer, der gik ned i lange Møttrikker. Det krævede, at Bindet aldrig kom under en vis Tykkelse, men det ordnede man ved at lægge hvide Blade ind bag $\mathrm{i}$ Bindet for at fylde ud. Nu staar Sedlerne i Kasser, som aabner sig til begge Sider, saa at de er lette at blade i. Publikum har lært ikke at tage Sedlerne ud.

Sofus Larsen ønskede, som han selv skrev i sine Mindeord om Birket-Smith, ${ }^{19}$ blot at føre det af ham paabegyndte Værk videre; men ingen har Fred, længere end hans Nabo vil, og der blev stadig mere og mere Uro om de københavnske Biblioteksforhold, saa Sofus Larsen maatte tage sin Del i den Diskussion, der opstod.

Jeg kommer lige til at ridse Konturerne op i de Problemer, der kom til Debat.

Indtil 1728 havde København haft to store Universalbiblioteker; Universitetsbiblioteket fra 1482 var det største; det Store Kongelige Bibliotek fra 1661 var ogsaa blevet et meget anseeligt Bibliotek. Da Universitetsbiblioteket efter Branden i 1728 maatte bygges op fra Grunden, gik man i Gang med at skaffe Universitetet et nyt Univer- 
sitetsbibliotek til Erstatning for det tabte; derimod gik Universitetsbibliotekets Stilling som Nationalbibliotek over til det Kongelige Bibliotek, som besad al den danske Litteratur fra før Branden, som man ikke kunde regne med at kunne genanskaffe, idet dog det Kongelige Bibliotek overlod Universitetsbiblioteket alle sine Dubletter. $^{20}$

Men denne Plan om to Universalbiblioteker, som kan have taget sig mulig ud i 1728, kom aldeles til kort over for den stadig stigende Produktion af Bøger, og allerede [J. N.] Madvig indsaa i 1842, at det vilde blive nødvendigt at afgrænse de to Bibliotekers Virkefelt, hvis Landet skulde kunne faa alle de Bøger, som var nødvendige. ${ }^{21}$ Efter at Universitetsbiblioteket i 1867 havde modtaget det Classenske Bibliotek, som rummede en stor Samling naturvidenskabelige Bøger, var det klart, at Delelinien maatte gaa saadan, at det Kongelige Bibliotek tog sig af Humaniora, medens Universitetsbiblioteket koncentrerede sig om Naturvidenskab og Medicin. ${ }^{22}$

Der var ogsaa gennemført en vis Specialisering i Bogkøbet, men noget virkeligt Samarbejde var der ikke Tale om. Det første alvorlige Forsøg paa at faa Samarbejdet i Gang blev gjort i 1902 med Oprettelsen af Accessionskatalogen, hvis Formaal var at forebygge overflødige Dubletkøb paa de store Biblioteker; men endnu i 1915, da jeg blev ansat ved Universitetsbiblioteket, maatte jeg ofte i Udlaanet forklare en Laaner, at British Medical Journal kunde jeg give ham, men the Lancet maatte han hente paa det Kongelige Bibliotek.

I 1911 bearbejdede Bibliotekar [ved det Kongelige Bibliotek, A. A.] Bjørnbo ${ }^{23}$ Accessionskatalogens Materiale for at vise, i hvor ringe Grad de to store Biblioteker havde forstaaet at indrette deres Bogkøb rationelt; han vilde have Accessionskatalogens Redaktør til at være en Mellemmand mellem de to Biblioteker for at ordne Indkøbene; og han havde ogsaa en samlet Plan for hele Biblioteksvæsenet. Sofus Larsen imødegik ham i en Række Artikler i "Riget « ${ }^{24}$ og hævdede, at der ikke var nogen Grund til at lave en ny, dyr Ordning. Specielt vendte han sig, og med fuld Ret, mod Bjørnbos Forslag om at gøre Laboratoriebibliotekerne delvis offentligt tilgængelige. Bjørnbo døde i 1911 og Sagen gik i staa, indtil Professor Poul Johannes Jørgensen i 1917 i Ministeriernes Maanedsblad ${ }^{25}$ kla- 
gede over, at der ud over Juridisk Laboratorium ikke var noget Bibliotek, der tog sig af udenlandsk juridisk Litteratur. Svend Dahl, som [da] var Underbibliotekar ved det Kongelige Bibliotek, skrev et Indlæg, ${ }^{26}$ hvori han gik ind for, at det Kongelige Bibliotek skulde tage sig af udenlandsk Jura, og at den kun skulde samles der. Saa skrev Sofus Larsen om "Fremtidens Fagcentraler $"{ }^{27}$ Han hævdede, at de mindre Fagbibliotekers to Problemer var Pladsmangel og Mangel paa skolet Arbejdskraft. Derfor skulde det Kongelige Bibliotek og Universitetsbiblioteket dele Fagene mellem sig og fungere som Overcentraler, der aflastede de mindre Fagbiblioteker for den forældede Litteratur. Han foreslog, at det Kongelige Bibliotek og Universitetsbiblioteket udvekslede den juridiske og medicinske Litteratur; og det skete ogsaa. ${ }^{28}$ Samtidig fik han ansat to medicinske Konsulenter til at hjælpe sig med Boganskaffelserne.

Dette var et Skridt i den rigtige Retning, og da det jo er det første Skridt, som koster, var det et meget betydende Skridt. Men nu tog Diskussionen først rigtig Fart. I 1918 udkom en Piece af Svend Dahl og [Læge] Carl With: "Vore naturhistoriske Museer og Biblioteker. Forslag til et Centralinstitut ". Planerne gik ud paa, at Delingen mellem de to store Biblioteker blev gennemført til Bunds; Universitetsbiblioteket skulde flyttes til en Bygning paa Gothersgade Kasernes Grund, hvor det skulde være Bibliotek for et Centralinstitut for naturvidenskabelig Forskning og have Opsigt med alle Fagbiblioteker under dette Omraade. Universitetsbiblioteket skulde opgive sit Pligteksemplar fra de danske Bogtrykkere. ${ }^{29}$

Sofus Larsen tog til Orde herimod i Nationaltidende. ${ }^{30}$ Han hævdede, at Universitetsbiblioteket, trods den begyndende Fagdeling, stadig havde sin Opgave som Universitetsbibliotek, om ikke for andet, saa som Reserve, hvis der skulde tilstøde det Kongelige Bibliotek noget. Pligtafleveringen med dens Konfirmationssange og Mejeriregnskaber turde han saaledes ikke give Afkald paa; Biblioteket maatte ikke flyttes fra sin Plads, og det og Museerne maatte ikke, som i Piecen foreslaaet, adskilles fra Universitetet.

I 1921 fremsatte Bibliotekar [Sigfús] Blöndal fra det Kongelige Bibliotek i Bogens Verden ${ }^{31}$ et Forslag til en samlet Ordning af hele det lærde Biblioteksvæsen i København, og i 1922 udkom en Piece af 
Bibliotekar [J. C.] Kall ved Universitetsbiblioteket: Universitetsbibliotekets Organisation og Fremtid, hvori han giver en meget interessant Redegørelse for Universitetsbibliotekets Historie fra 1840 med de mange Planer, der siden da er blevet fremsat om en Ordning af Biblioteksforholdene, især Forholdet mellem de to store Biblioteker.

Sofus Larsen anmelder Bogen i Nationaltidende, ${ }^{32}$ og han er meget forbitret. For det første fordi den er udkommet uden hans Vidende, skønt han aldrig har lagt noget Baand paa sine Medarbejderes Ytringsfrihed. Dette er aldeles rigtigt. Jeg har selv deltaget $i$ Diskussionen, dels med Indlæg om Blöndals Forslag, ${ }^{33}$ dels med en lang Anmeldelse af Kalls Piece i Ministeriernes Maanedsblad. ${ }^{34}$ Jeg meddelte Sofus Larsen min Hensigt og fik den Besked, at jeg kunde skrive, hvad jeg vilde, blot jeg gjorde opmærksom paa, at jeg skrev for egen Regning og ikke udtrykte nogen almindelig Mening blandt mine Kolleger. Da dette var i absolut Overensstemmelse med de faktiske Forhold, fandt jeg ikke denne Betingelse uopfyldelig.

Dernæst var Sofus Larsen meget opbragt over Kalls Omtale af Birket-Smith, som han i øvrigt med Urette finder "vidner om en indeklemt personlig Rancune, der, naar den i en saadan Form giver sig Luft længe efter Vedkommendes Død, forekommer mig dobbelt tarvelig og usmagelig."

Kalls Forslag om Bibliotekets Nyordning var en Videreførelse af Blöndals Forslag med nogle af mig foreslaaede Andringer. ${ }^{35} \mathrm{Bi}-$ blioteket skulde deles; Centralbiblioteket for Naturvidenskab og Medicin skulde flyttes bort, men i Fiolstræde skulde den humanistiske Del gøres til et Universitetsbibliotek efter Retningslinier, som H. O. Lange ${ }^{36}$ havde angivet for et eventuelt Universitetsbibliotek i Aarhus: et Bibliotek til Brug for de Studier, der netop drives paa Frue Plads, altid à jour, absolut intet Bogmuseum. Pligtafleveringen skulde bortfalde, forældet Litteratur afskaffes.

Herimod indvendte Sofus Larsen, at det var Utopier, som var økonomisk uigennemførlige; at Biblioteket ikke maatte deles; at det skulde blive i Fiolstræde og overtage Zoologisk Museums Bygning, naar Museet fik sit haardt tiltrængte nye Hus; og at det burde beholde Pligtafleveringen. 
Netop Pligtafleveringen blev det Punkt, hvorom Sofus Larsens sidste Bidrag til Biblioteksdiskussionen kom til at dreje sig. Lauritz Nielsen fra det Kongelige Bibliotek skrev en Piece, ${ }^{37}$ hvori han blandt andet foreslog, at Universitetsbiblioteket i Stedet for Pligtaflevering fra Bogtrykkere skulde have Rekvisitionsret. Sofus Larsen anmeldte Piecen i Dagens Nyheder den 17. januar 1924; han hævdede, at en Rekvisitionsret vilde være illusorisk, og at alt burde blive ved det gamle. Carl S. Petersen, [det Kongelige Bibliotek], tog til Genmæle, ${ }^{38}$ og der kom flere Bidrag fra hver Side, ${ }^{39}$ uden at nogen af Parterne ændrede Standpunkt.

Sammenfattende kan man sige, at Sofus Larsen ikke var nogen Modstander af nye Tanker. Han gennemførte den første Udveksling af Bøger med det Kongelige Bibliotek, og hans Forslag om Fremtidens Fagcentraler indeholdt meget godt og blev retningsgivende for de senere Reformer. Men han kom ikke til at staa som den store Reformator af vort Biblioteksvæsen, fordi han veg tilbage for at tage Konsekvenserne, nemlig at opgive Tanken om Universitetsbiblioteket som Universalbibliotek og dermed dets Ligestilling med det Kongelige Bibliotek. Det var til syvende og sidst et Prestigespørgsmaal, og hvor Prestigedjævlen kommer ind ad Døren, flyver Sagligheden ud af Vinduet.

I 1925 fyldte Sofus Larsen 70 Aar og fratraadte sin Stilling; sin litterære Virksomhed fortsatte han til 1938, da han døde, 83 Aar gammel.

Jeg har hermed søgt at give en saglig Fremstilling af Sofus Larsens Liv, Person og Virke. Jeg har tidligere betegnet ham som en velmenende Dilettant. At han var velmenende, at han med stor Iver brugte de Evner, han havde, til at gøre sin bedste Indsats i Bibliotekets Tjeneste, turde fremgaa klart af min Fremstilling; for at forklare, hvorfor jeg anser ham for en Dilettant, maa jeg gøre Rede for mine Erfaringer i de ti Aar, fra 1915 til 1925, da jeg var hans Medarbejder.

Dilettanteriet gik tilbage til Birket-Smiths $\mathrm{Tid},{ }^{40}$ og havde sit grelleste Udtryk i Indretningen af Reolerne i den nye Bygning fra 1906, hvor Oktavhylderne blev gjort $2 \mathrm{~cm}$ lavere end i Gamle Bygning. Det medførte, at naar en Afdeling skulde flyttes derud, maatte 
nogle Procent af Oktavbøgerne flyttes til Kvarto, med Rettelse af: alle Katalogsedlerne.

Realkatalogerne i Skruebind har jeg omtalt. Da der ikke kunde sættes Sedler ind, hver Gang en Bog blev indført, maatte der skrives en foreløbig Strimmel, som laa paa Sedlens Plads, til det blev Tid at rense Skruebindet, d.v.s. at løse det op og lægge de store Sedler ind, samt tilføje paa de gamle Sedler, nye Oplag, nye Bind, og lignende. Men det krævede een overflødig Seddel for hver Bog.

Værre var det, at Skruebindene ikke kunde indeholde Fanekort; derfor maatte det, som skulde have staaet paa Fanekortet, skrives paa hver eneste Seddel. Det var aldrig under een Linie, ofte to hele Linier, og forøgede saaledes hver Indførsel i Systematisk Katalog med fra 20 til 100 pCt. Det var begyndt under Birket-Smith, og fortsatte uanfægtet under Sofus Larsen.

Der anvendtes springende Numre, femcifrede Tal. I nogle Kataloger gik man kun til 20.000 eller 30.000 , som om man sparede noget ved ikke at bruge alle de 99.999 Numre, som kan skrives med fem Cifre. ${ }^{41}$ Deweys Decimalnotering er fra 1876; alligevel brugte man Skraastreg og Brøk, naar Numrene, hvad de hurtigt gjorde, slap op. Da mange af Grupperne var ordnede alfabetisk, kunde man have brugt Cutternumre; men Amerika laa meget langt borte den Gang.

Værre endnu var, at Gruppens almindelige Del: Bibliografi, Boghistorie, Fagets Historie, Kongresser, Møder, Museer, Indledning o.s.v., ikke var ordnet ens i alle Grupper. Man havde stolet paa Hukommelsen, og ingen havde tænkt paa een Gang for alle at lave et Skema, som bare kunde følges.

Jeg kom ind paa Biblioteket i 1915 under 1. Verdenskrig. 11922 var Verden kommet saa meget i Lave, at jeg kunde tage til München, hvor jeg i tre Uger studerede Statsbibliotekets Indretning. I 1923 var jeg med Understøttelse fra Undervisningsministeriet i England og studerede British Museums Bibliotek og Bodleian Library. Det var til stor Glæde for mig selv, men til liden Gavn for Biblioteket, for ingen interesserede sig for det. Det var Universitetsbiblioteket ikke ene om. Jeg ringede til Victor Madsen ved det Kongelige Bibliotek; han var Redaktør af det nystartede Nordisk Tidsskrift for Bog- og 
Biblioteksvæsen, og jeg tilbød ham nogle Artikler om mine Erfaringer. Det havde ingen Interesse. Bibliotekshistorie og Boghistorie og alskens bibliofile Snurrepiberier kunde man bruge, men selve Biblioteksarbejdets Teori og Teknik, Katalogiseringsproblemer og praktiske Indretninger, det laa under en Bibliotekars Værdighed at give sig af med den Slags Ting.

Jeg skrev saa en lille Artikel til Zentralblatt für Bibliothekswissenschaft; den blev trykt i $1928 .{ }^{42}$

I 1924 kom J. Christian Bay ${ }^{43}$ til København og besøgte Biblioteket, og her lærte jeg ham at kende. Han sagde, at hvis jeg kunde faa American Scandinavian Foundations Stipendium, kunde han skaffe mig ind paa John Crerar Library i Chicago, som Indledning til mit Studieophold i de Forenede Stater. Jeg søgte Stipendiet. Sofus Larsen gav mig sin bedste Anbefaling og skrev, at det vilde være meget interessant for mig at komme til Amerika og se paa Biblioteker. Jeg fik ikke noget. Jeg søgte igen næste Aar, fik samme Anbefaling, og samme Resultat.

Paa dette Tidspunkt var jeg faktisk godt ked af min Virksomhed paa Biblioteket. Jeg passede Tidsskriftaccessionen, fotograferede, ordnede Smaatryk og indførte Bøger i systematisk Katalog - lærde Værker nu og da, men mest Romaner, Børnebøger, oversatte Knaldromaner og de ligegyldigste Ting fra den danske Pligtaflevering. Det hele føltes saa formaalsløst. Jeg overvejede at søge til Nationalmuseet.

$\mathrm{Nu}$ stod Sofus Larsens Afgang for Døren. Vi vidste, at Sofus Larsen vilde gaa ind for Krarup, men Erichsen søgte ogsaa, og nogle af os haabede paa, at det blev ham. Under Krarup vilde Sofus Larsens Linie være blevet fortsat. En Tid syntes Rafael Meyer fra Landbohøjskolens Bibliotek at have en Chance; men han døde, før Sagen blev aktuel. Nu søgte Biblioteksinspektør Svend Dahl. Han havde ganske vist arbejdet baade paa Universitetsbiblioteket og paa det Kongelige Bibliotek; men han var dog nu Folkebiblioteksmand.

Det var Konsistorium, der skulde træffe Afgørelsen. Efter Forlydende fik Krarup een Stemme, Erichsen fem, Svend Dahl Resten. Desværre blev Sofus Larsen saa fortørnet herover, at han forlod 
Biblioteket i Vrede og ikke vilde modtage Svend Dahls Tilbud om en Arbejdsplads paa Biblioteket. Det var hans Barnlighed, der her gav sig Udslag.

Saa gik det, som der staar i et Digt af Byron, oversat af Poul Martin Møller: Brat kom Forvandling over Drømmens Aand.

Vor nye Chef var en Fagmand. Han havde store Planer og arbejdede paa langt Sigt. Han kendte Biblioteksgerningens Teori og Praksis og kunde ordne alle Detailler. Jeg husker tydeligt mit første rigtige Møde med ham. Han kom ind paa Tidsskriftlæsestuen, hvor der paa en Hylde laa en Dynge Brochurer, Ting fra Verdenskrigen, som var sendt til Biblioteket og nu ventede paa at blive indført. Jeg tog Bunken ned og lagde den paa Skrivemaskinebordet. Den var meget støvet, og Svend Dahl var noget pillen. Han tog en stor Saks, saa paa Hæfterne, og ragede dem ned i Papirkurven eet for eet. Saa var den Sag ordnet. Men jeg oplevede for første Gang, at det ikke var nødvendigt for Biblioteket at beholde en Tryksag, blot fordi den var kommet inden for Døren. Svend Dahl var Bibliotekets Herre, hvor Sofus Larsen havde været dets Tjener.

Næste Foraar søgte jeg igen om at komme til Amerika. Svend Dahl skrev i sin Anbefaling, at det vilde være af den største Interesse for Biblioteket, at jeg kom derover og fik set de amerikanske Biblioteker. Saa kom jeg af Sted, og efter min Hjemkomst fik jeg meget at gøre med Planlægning af den nye Bygning ude paa Fælleden. Jeg havde ikke den ringeste Lyst til at søge bort; mit Arbejde havde faaet Mening.

Man hører tit, naar en Mand skal tiltræde en Post efter en særlig fremragende Forgænger, at det maa ikke være let at komme efter netop den Mand. I dette Tilfælde kunde jeg sige, at det var ikke let for Sofus Larsen at komme før Svend Dahl. Det Billede af ham, der i Tidens Løb havde nedfældet sig hos mig, var ikke saa lidt paavirket af alt det, der skete efter hans Afgang, og mit Forsøg paa at give en retfærdig Skildring af ham er i Virkeligheden blevet en Art Rehabilitering af hans Minde. Det har glædet mig, og jeg er Bibliotekarsammenslutningen taknemmelig, fordi den har betroet mig denne Opgave. 


\section{NOTER}

1. Han var også selv "temmelig velhavende« med hus, sommerhus og vinterlejlighed. - C. Dumreicher: Mellem bøger og biblioteker. Små livserindringer. Kbh. 1959. S. 65

2. Dansk Biografisk Leksikon (DBL), 2.udg., bd.XIV. 1938. S. 77-79. DBL, 3. udg. (genoptryk af artiklen) bd. VIII. 1981. S. 575-76.

3. DBL, 2. udg., bd. XIV. 1938. S. 79-81 af Carl Dumreicher. DBL, 3. udg., bd. VIII. 1981. S. 577-78 af Palle Birkelund.

4. I manuskriptet gengiver Drachmann de samme fejl i de bibliografiske data, som findes i DBL, 2.udg. Disse fejl er rettet såvel i DBL, 3. udg. som i teksten.

5. Niels Ebbesen. Kbh. 1908. I kapitlet Synspunkter for Visekritikken, særlig s. 7-8.

6. Anf. skr. S. 306-10, citatet s. 310 .

7. Drachmanns biografi i DBL, 3. udg., bd. IV. 1980. S. 31 af Palle Birkelund.

8. Hans villa - i dag noget skæmmet af en tilbygning - ligger på Furesøvej i Virum, på en stor grund ned mod søen og med Kaningården som nabo.

9. Dumreichers kortere beskrivelse indeholder stort set de samme træk. I: Anf. skr. S. 62-64.

10. S. Birket-Smith in memoriam. I: Anf. skr. S. 10-14.

11. Udtrykket er afledt af J. C. Kalls betegnelse "at kløve Brænde med Rageknive« $i$ Københavnske Biblioteksforhold. I: Tilskueren 1924. S. 169.

12. Jf. Dumreicher. Anf. skr. S. 81-83.

13. Anf. skr. S. 68-71.

14. Danish Eighteenth Century Bindings 1730-1780. Kbh. 1930.

15. Chr. Winther (1873-1968), professor i kemi ved Polyteknisk Læreanstalt og forstander for dens Fotokemisk-fotografisk Laboratorium, jf. DBL, 2. udg., bd. XXVI. 1944. S. 128-29 og 3. udg., bd. XV. 1984. S. 617-18.

16. Dette har Dumreicher nu ikke noget om, til gengæld er dette forhold omtalt i J. C. Kall: Universitetsbibliotekets Organisation og Fremtid. Kbh. 1922. S. 51.

17. Om personaleforholdene på Universitetsbiblioteket se Betænkning vedrørende Statens Biblioteksvæsen. Kbh. 1927. S. 188-89. Det fremhæves her, at der kun er ansat to kontorassistenter, hvorved "meget af det Arbejde, der kunde udføres af Kontorassistenter, derfor maa besørges af det videnskabeligt uddannede Personale«.

18. I manuskriptet er der sat parentes om en næsten halv side lang teknisk udredning, som er erstattet af det sidste punktum, som er tilføjet i marginen.

19. Ex Bibliotheca Universitatis Hauniensis. 1920. S. 12.

20. Se s. 365-67 i Palle Birkelund: Universitetsbiblioteket 1729-1926. I: Københavns Universitet 1479-1979, bd. IV. 1980. S. 365-454.

21. Universitetets Aarbog 1842. S. 10.

22. En noget forenklet fremstilling af et mere kompliceret sagsforløb, jf. s. 421-429 
i Birkelund, anf. skr., og s. 182-183 i M. de Hartyani: Det mærkværdige Amfibium. I: Bibliotek for læger, bd. CLXXIV, suppl. 1. 1982. S. 181-228.

23. A. A. Bjørnbo: Statens Bogkøb. Kbh. 1911.

24. Sofus Larsen: Københavnske Biblioteksforhold. Kbh. 1911.

25. Det juridiske Laboratorium. I: Anf. skr. S. 58-61.

26. Den juridiske Litteratur i vore offentlige Biblioteker. I: Anf. skr. S. 88-91.

27. Ssteds, s. 298-302.

28. Hartyani. Anf. skr. S. 196-98.

29. With og Dahls plan er udførligt behandlet af. Kall: Universitetsbibliotekets ... S. $67-82$.

30. 31.januar, 1. og 19. februar 1918.

31. Københavnske Biblioteksforhold. Nogle Tanker om Samarbejde og Organisation. I: Bogens Verden, bd. III. 1921. S. 55-61, 96-103, 143-48.

32. Er Universitetsbibliotekets Eksistens truet. 14. november 1922.

33. Universitetsbibliotekets Fremtid. I: Bogens Verden, bd. III. 1921. S. 177-79.

34. Universitetsbibliotekets Organisation og Fremtid. I: Anf. skr. 1922. S. 93-97.

35. Jf. Hartyani. Anf. skr. S. 205-08.

36. Et Universitetsbibliotek i Aarhus. I: Bogens Verden, bd. III. 1921. S. 131-36.

37. Pligtafleveringen til vore Biblioteker. Et Reformforslag. Kbh. 1923.

38. Carl S. Petersen: Bibliotekerne og Pligtafleveringen. Nationaltidende, 23.januar 1924.

39. Nationaltidende, 30. januar, 7., 13. og 18. februar 1924.

40. Jf. efterskriften. S. $147 \mathrm{f}$..

41. Enkelte af katalogerne har siden benyttet seks cifre. Systemet er siden blevet ændret, både på UB1 og UB2.

42. A. G. Drachmann: Realkatalog oder Standortskatalog. I: Zentralblatt für Bibliotekswesen, bd. 45. 1928. S. 42-45.

43. Dansk-amerikansk biblioteksmand. Se DBL, 3. udg., bd. I. 1979. S. 501-02. 